\title{
Botryosphaeriaceae species associated with lentisk dieback in Italy and description of Diplodia insularis sp. nov.
}

\author{
Linaldeddu BT ${ }^{1}$, Maddau L ${ }^{1}$, Franceschini $\mathrm{A}^{1}$, Alves $\mathrm{A}^{2}$ and Phillips $\mathrm{AJL}^{3}$ \\ ${ }^{I}$ Dipartimento di Agraria, Sezione di Patologia vegetale ed Entomologia, Università degli Studi di Sassari, Viale Italia \\ 39, 07100 Sassari, Italy \\ ${ }^{2}$ Departamento de Biologia, CESAM, Universidade de Aveiro, 3810-193 Aveiro, Portugal \\ ${ }^{3}$ Biosystems and Integrative Sciences Institute, Faculty of Science, University of Lisbon, Campo Grande, 1749-016 \\ Lisbon, Portugal
}

Linaldeddu BT, Maddau L, Franceschini A, Alves A, Phillips AJL 2016 - Botryosphaeriaceae species associated with lentisk dieback in Italy and description of Diplodia insularis sp. nov. Mycosphere 7(7), 962-977, Doi 10.5943/mycosphere/si/1b/8

\begin{abstract}
Lentisk (Pistacia lentiscus L.) is an evergreen shrub that is widespread throughout the Mediterranean region. Since spring 2012, a severe and unusual disease of unknown aetiology has been observed on lentisk in six islands of the La Maddalena archipelago (Italy). The affected plants showed leaf chlorosis, crown thinning, branch dieback and sunken cankers. When branches with sunken cankers were cross-sectioned, internal wood symptoms included characteristic V-shaped necrotic sectors. Frequently, the necrotic lesions girdled the branches resulting in death of the upper crowns. Since there is no information about the aetiology of this disease and given the high ecological importance of these natural ecosystems, from spring 2012 to summer 2014, 37 samples of twigs and branches of lentisk showing sunken cankers were collected and processed. Symptomatic woody samples yielded fungal isolates representing two distinct genera in the Botryosphaeriaceae. On the basis of morphological features and DNA sequence data three distinct species: Diplodia olivarum, Neofusicoccum cryptoaustrale and N. luteum were identified. In addition, another Diplodia species morphologically distinct from all known species was isolated. Phylogenetic analyses based on nucleotide sequences of ITS and tefl- $\alpha$ regions showed that this new Diplodia species is most closely related to D. pseudoseriata and D. alatafructa. Pathogenicity trials carried out in field conditions on asymptomatic branches of lentisk showed that all four species are aggressive pathogens on this host and therefore directly involved in the severe dieback that is currently threatening this typical shrub of the Mediterranean maquis.
\end{abstract}

Key words - Diplodia - Mediterranean maquis - Neofusicoccum - pathogenicity - phylogeny

\section{Introduction}

The La Maddalena archipelago (north-eastern Sardinia, Italy) is considered a hot spot of biodiversity characterized by a large number of endemic species and multiple habitats typical of the Mediterranean climate (Bocchieri 1992). The archipelago comprises 7 major islands and more than 50 small islets. The natural vegetation of the main islands is characterized by evergreen forest trees such as Juniperus phoenicea, Olea europaea var. sylvestris, Quercus ilex, Salix atrocinerea and Tamarix africana, mixed with species typical of the Mediterranean maquis such as Arbutus unedo, 
Erica arborea, Myrtus communis, Phillyrea angustifolia, Pistacia lentiscus and Rhamnus alaternus (Biondi \& Bagella 2005).

Since 2008, a severe and widespread decline and mortality affecting several of these Mediterranean species has been recognized on Caprera island. Results of etiological studies carried out to establish the cause of these phenomena have revealed the primary role played by some species belonging to the genera Diplodia and Neofusicoccum. In particular, Diplodia corticola and Neofusicoccum parvum have been detected as the species most directly involved in the aetiology of decline affecting $Q$. ilex trees (Linaldeddu et al. 2014), Diplodia africana, Neofusicoccum australe and $N$. cryptoaustrale have been consistently associated with different disease symptoms on branches of J. phoenicea (Linaldeddu et al. 2011, Andolfi et al. 2012), while Neofusicoccum luteum has been recognized as the causal agent of a new disease of $E$. arborea (Linaldeddu et al. 2015b).

Furthermore, since spring 2012, a new disease of unknown aetiology has been observed on $P$. lentiscus (lentisk) in six of the main islands belonging to the La Maddalena archipelago. Since there is no information about the cause of this disease and given the high ecological importance of these natural ecosystems, the aim of this study was to clarify the aetiology of this new disease and determine the virulence of the major fungal species associated.

\section{Materials \& Methods}

\section{Field surveys and sampling procedure}

Field surveys were carried out from spring 2012 to summer 2014 in six of the main islands belonging to the La Maddalena archipelago (Budelli, Caprera, Mortorio, Santa Maria, Santo Stefano and Spargi). A circular monitoring plot (MP, diameter $10 \mathrm{~m}$ ) was established in each island (two in Caprera), and the geographic coordinates of plots were recorded by a portable GPS ( $e$ Trex, Garmin). The location of plots was based on the results of a preliminary survey about occurrence and distribution of symptomatic plants. At each MP, the number of trees was detected and their health status was assessed based on the occurrence of symptoms such as dieback, exudates, cankers and epicormic shoots. From each symptomatic plant a branch showing an active canker was collected. In total, 37 plants were sampled (Table 1).

\section{Isolation and morphological characterization of canker-associated fungi}

Symptomatic branch samples were taken to the laboratory and the outer bark surface tissue was cut away with a scalpel. Longitudinal and transversal cuts from symptomatic branch samples revealed internal symptoms. Fungi were isolated from chips of inner bark and xylem tissue ( $\sim 5$ $\mathrm{mm}^{2}$ ) removed from the margin of necrotic lesions with a sterile scalpel. All chips were cultured on potato dextrose agar (PDA, Oxoid Ltd., Basingstoke, UK) in Petri dishes. After incubation at $25^{\circ} \mathrm{C}$ for 5-7 days in the dark, fungal colonies were sub-cultured onto half-strength PDA supplemented with autoclaved $Q$. ilex and $P$. lentiscus twigs and incubated at room temperature under natural daylight until pycnidia developed.

For each fungal species, colony growth characteristics including surface and reverse colony appearance were observed and recorded after 7 days of incubation at $25^{\circ} \mathrm{C}$ in the dark on PDA. Identification of isolates to species level was based on colony and conidial morphology as described by Phillips et al. (2013).

For novel species, cardinal temperatures for growth were determined on plates of PDA incubated at $5,10,15,20,25,30$ and $35^{\circ} \mathrm{C}\left( \pm 0.5^{\circ} \mathrm{C}\right)$ in the dark. Five replicate plates for each isolate were made and colony diameters were measured after 4 days. For microscopy, the contents of conidiomata were dissected and mounted in 100\% lactic acid. Measurements of conidiogenous cells and conidia were made with the Leica IM 500 measurement module from images recorded with the $\times 100$ objective on a Leica DFC 320 digital camera. Spore dimensions are presented as mean values of 50 conidia with extreme values in parentheses. Dimensions of other structures are given as means of at least 20 measurements. 
Table 1 Characteristics of the seven monitoring plots and number of Pistacia lentiscus plants sampled.

\begin{tabular}{llllll}
\hline Island & Plot & Latitude & Longitude & $\begin{array}{l}\text { Number of plants } \\
\text { Total }\end{array}$ & Sampled \\
\hline Budelli & 1 & $41^{\circ} 16^{\prime} 48^{\prime \prime} \mathrm{N}$ & $09^{\circ} 21^{\prime} 22^{\prime \prime} \mathrm{E}$ & 3 & 3 \\
Caprera & 2 & $41^{\circ} 12^{\prime} 51^{\prime \prime} \mathrm{N}$ & $09^{\circ} 27^{\prime} 01^{\prime \prime} \mathrm{E}$ & 12 & 10 \\
& 3 & $41^{\circ} 12^{\prime} 36^{\prime \prime} \mathrm{N}$ & $09^{\circ} 27^{\prime} 42^{\prime \prime} \mathrm{E}$ & 8 & 8 \\
Mortorio & 4 & $41^{\circ} 04^{\prime} 28^{\prime \prime} \mathrm{N}$ & $09^{\circ} 36^{\prime} 10^{\prime \prime} \mathrm{E}$ & 13 & 6 \\
Santa Maria & 5 & $41^{\circ} 17^{\prime} 47^{\prime} \mathrm{N}$ & $09^{\circ} 22^{\prime} 25^{\prime \prime} \mathrm{E}$ & 5 & 3 \\
Santo Stefano & 6 & $41^{\circ} 11^{\prime} 56^{\prime \prime} \mathrm{N}$ & $09^{\circ} 24^{\prime} 38^{\prime \prime} \mathrm{E}$ & 5 & 5 \\
Spargi & 7 & $41^{\circ} 14^{\prime} 04^{\prime} \mathrm{N}$ & $09^{\circ} 21^{\prime} 11^{\prime \prime} \mathrm{E}$ & 2 & 2 \\
\hline
\end{tabular}

Table 2 Diplodia isolates included in the phylogenetic analyses. The newly generated sequences are indicated in italics and ex-type strains in bold face.

\begin{tabular}{|c|c|c|c|c|c|}
\hline \multirow{2}{*}{ Isolate number } & \multirow{2}{*}{ Species } & \multirow{2}{*}{ Host } & \multirow{2}{*}{ Country } & \multicolumn{2}{|c|}{ GenBank accession number } \\
\hline & & & & ITS & tef1- $\alpha$ \\
\hline CBS 120835 & D. africana & Prunus persica & South Africa & EF445343 & EF445382 \\
\hline CBS 121104 & D. africana & P. persica & South Africa & EF445344 & EF445383 \\
\hline CBS 132777 & D. agrifolia & Quercus agrifolia & USA & JN693507 & JQ517317 \\
\hline UCROK1429 & D. agrifolia & Q. agrifolia & USA & JQ411412 & JQ512121 \\
\hline CBS 124931 & D. alatafructa & Pterocarpus angolensis & South Africa & FJ888460 & FJ888444 \\
\hline CBS 130408 & D. allocellula & Acacia karroo & South Africa & JQ239397 & JQ239384 \\
\hline CBS 130410 & D. allocellula & A. karroo & South Africa & JQ239399 & JQ239386 \\
\hline CBS 124254 & D. bulgarica & Malus sylvestris & Bulgaria & GQ923853 & GQ923821 \\
\hline CBS 124135 & D. bulgarica & M. sylvestris & Bulgaria & GQ923852 & GQ923820 \\
\hline CBS 112549 & D. corticola & Quercus suber & Portugal & AY259100 & AY573227 \\
\hline BL7 & D. corticola & Quercus afares & Tunisia & JX894190 & JX894209 \\
\hline BL10 & D. corticola & Quercus ilex & Italy & JX894191 & JX894210 \\
\hline BL11 & D. corticola & Q. ilex & Italy & JX894192 & JX894211 \\
\hline MFLUCC 15-0648 & D. crataegicola & Crataegus sp. & Italy & KT290244 & KT290248 \\
\hline CBS 168.87 & D. cupressi & Cupressus sempervirens & Israel & DQ458893 & DQ458878 \\
\hline BL102 & D. cupressi & C. sempervirens & Tunisia & KF307722 & KF318769 \\
\hline CBS 140851 & D. eriobotryicola & Eriobotrya japonica & Spain & KT240355 & KT240193 \\
\hline CBS 136010 & D. fraxini & Fraxinus angustifolia & Portugal & KF307700 & KF318747 \\
\hline CBS 136013 & D. fraxini & F. angustifolia & Italy & KF307710 & KF318757 \\
\hline MFLUCC 15-0647 & D. galiicola & Galium sp. & Italy & KT290245 & KT290249 \\
\hline CBS 129750 & D. guayanensis & Acacia mangium & Venezuela & JX545108 & JX545126 \\
\hline CBS 129749 & D. guayanensis & A. mangium & Venezuela & JX545106 & JX545128 \\
\hline GUCC 0922-1 & D. huaxii & Platanus sp. & China & KU848201 & - \\
\hline MFLUCC 14-1007 & D. italica & Crataegus sp & Italy & KU848202 & - \\
\hline CBS 124462 & D. intermedia & M. sylvestris & Portugal & GQ923858 & GQ923826 \\
\hline CBS 112556 & D. intermedia & M. sylvestris & Portugal & AY259096 & GQ923851 \\
\hline CBS 140350 & D. insularis & Pistacia lentiscus & Italy & KX833072 & KX833073 \\
\hline BL99 & D. insularis & P. lentiscus & Italy & KX833074 & $K X 833075$ \\
\hline BL183 & D. insularis & P. lentiscus & Italy & $K X 833076$ & KX833077 \\
\hline BL132 & D. insularis & F. angustifolia & Italy & KF307720 & KF318767 \\
\hline BL133 & D. insularis & F. angustifolia & Italy & KF307721 & KF318768 \\
\hline $\mathrm{BN}-55$ & D. insularis & E. japonica & Spain & KT240361 & KT240275 \\
\hline
\end{tabular}




\begin{tabular}{|c|c|c|c|c|c|}
\hline \multirow{2}{*}{ Isolate number } & \multirow{2}{*}{ Species } & \multirow{2}{*}{ Host } & \multirow{2}{*}{ Country } & \multicolumn{2}{|c|}{ GenBank accession number } \\
\hline & & & & ITS & tef1- $\alpha$ \\
\hline CBS 124130 & D. malorum & M. sylvestris & Portugal & GQ923865 & GQ923833 \\
\hline BL127 & D. malorum & Populus alba & Italy & KF307717 & KF318764 \\
\hline CBS 136014 & D. mutila & P. alba & Portugal & KJ361837 & KJ361829 \\
\hline CBS122553 & D. mutila & Vitis vinifera & Portugal & AY259093 & AY573219 \\
\hline CPC 22753 & D. neojuniperi & Juniperus chinensis & Thailand & KM006431 & KM006462 \\
\hline СРC 22754 & D. neojuniperi & J. chinensis & Thailand & KM006432 & KM006463 \\
\hline CBS 121887 & D. olivarum & Olea europaea & Italy & EU392302 & EU392279 \\
\hline BL96 & D. olivarum & P. lentiscus & Italy & KX833078 & KX833079 \\
\hline CBS 124906 & D. pseudoseriata & B. salicifolius & Uruguay & EU080927 & EU863181 \\
\hline GUCC G603-1 & D. pseudoplatani & Platanus sp. & China & KU848200 & - \\
\hline CBS 133852 & D. quercivora & Quercus canariensis & Tunisia & JX894205 & JX894229 \\
\hline CBS 133853 & D. quercivora & Q. canariensis & Tunisia & JX894206 & JX894230 \\
\hline CBS 116470 & D. rosulata & Prunus africana & Ethiopia & EU430265 & EU430267 \\
\hline CBS 116472 & D. rosulata & P. africana & Ethiopia & EU430266 & EU430268 \\
\hline CBS 393.84 & D. sapinea & Pinus nigra & Netherlands & DQ458895 & DQ458880 \\
\hline CBS 109725 & D. sapinea & Pinus patula & Indonesia & DQ458896 & DQ458881 \\
\hline CBS 109943 & D. sapinea & P. patula & Indonesia & DQ458898 & DQ458883 \\
\hline BL103 & D. sapinea & Retama raetam & Tunisia & KX833080 & KX833081 \\
\hline BL189 & D. sapinea & Corylus avellana & Italy & KX833082 & KX833083 \\
\hline CBS 118110 & D. scrobiculata & Pinus banksiana & USA & KF766160 & KF766399 \\
\hline CBS 109944 & D. scrobiculata & Pinus greggii & Mexico & DQ458899 & DQ458884 \\
\hline CBS 113423 & D. scrobiculata & P. greggii & Mexico & DQ458900 & DQ458885 \\
\hline CAP163 & D. scrobiculata & O. europaea & Italy & EU392283 & EU392260 \\
\hline BL5 & D. scrobiculata & Arbutus unedo & Italy & GU722102 & JX894231 \\
\hline CBS 112555 & D. seriata & $V$. vinifera & Portugal & AY259094 & AY573220 \\
\hline CBS 119049 & D. seriata & $V$. vinifera & Italy & DQ458889 & DQ458874 \\
\hline CAA502 & D. seriata & Fraxinus ornus & Portugal & KJ361842 & KJ361836 \\
\hline BL130 & D. seriata & F. angustifolia & Italy & KF307723 & KF318770 \\
\hline CBS 124133 & D. subglobosa & Lonicera nigra & Spain & GQ923856 & GQ923824 \\
\hline CBS 124131 & D. subglobosa & F. ornus & Italy & GQ923855 & GQ923823 \\
\hline CBS 418.64 & D. tsugae & Tsuga heterophylla & Canada & DQ458888 & DQ458873 \\
\hline
\end{tabular}

Acronyms of culture collections: BL: B.T. Linaldeddu culture collection housed at Dipartimento di Agraria, Università di Sassari, Italy; CAA: Collection of Artur Alves housed at Department of Biology, University of Aveiro, Portugal; CAP, A.J.L. Phillips, Universidade Nova de Lisboa, Portugal; CBS: Centraalbureau voor Schimmelcultures, The Netherlands; CPC: Collection of Pedro Crous housed at CBS; UCROK, Department of Plant Pathology and Microbiology, University of California, Riverside; GUCC: Guizhou University Culture Collection (GUCC); MFLUCC: Mae Fah Luang University Culture Collection.

Representative isolates of each species were stored on PDA slants under oil in the culture collection of the Sez. di Patologia Vegetale ed Entomologia, Dipartimento di Agraria at the University of Sassari. A representative culture of the new Diplodia species was also deposited at the Centraalbureau voor Schimmelcultures (CBS), Utrecht, the Netherlands and nomenclatural data in MycoBank (Crous et al. 2004) and Faces of Fungi (Jayasiri et al. 2015) databases. The holotype was lodged with the herbarium of Instituto Nacional de Investigação Agrária e Veterinária I.P., Oeiras, Portugal (LISE).

\section{DNA extraction, PCR amplification and sequencing}

Genomic DNA was extracted from 5-day-old cultures grown on PDA at $25^{\circ} \mathrm{C}$ using Instagene Matrix (BioRad Laboratories, Hercules, California, USA). The internal transcribed 
spacer (ITS) region of the ribosomal DNA was amplified and sequenced using primers ITS 1 and ITS4 (White et al. 1990), while part of the translation elongation factor 1 alpha gene (tefl- $\alpha$ ) was amplified and sequenced with primers EF446f and EF1035r (Inderbitzin et al. 2010). PCR amplification was carried out as described by Linaldeddu et al. (2013) and the products were purified using the EUROGOLD gel extraction kit according to the manufacturer's instructions (EuroClone S.p.A., Pero, Italy). Both strands were sequenced by the BMR Genomics DNA sequencing service. Sequences were edited with FinchTV v1.4.0 (Geospiza, Inc., Seattle, Washington, USA) and compared with sequences deposited in GenBank using the BLAST algorithm. New sequences were deposited in GenBank (Table 2 \& Table 4) and alignments in TreeBase (S19828).

\section{Phylogenetic analyses}

ITS and tefl- $\alpha$ sequences of the isolates obtained in this study were combined and aligned with sequences retrieved from GenBank, representing all 28 Diplodia species known from culture. Alignments were done with ClustalX v. 1.83 (Thompson et al. 1997) using the following parameters: pairwise alignment parameters (gap opening $=10$, gap extension $=0.1$ ) and multiple alignment parameters (gap opening $=10$, gap extension $=0.2$, transition weight $=0.5$, delay divergent sequences $=25 \%$ ). Alignments were checked and manual adjustments made if necessary using BioEdit v. 7.2.5 (Hall 1999). Maximum likelihood (ML) analyses were done using MEGA6 (Tamura et al. 2013) using the best fitting DNA evolution model determined by the program. ML analyses were performed on a Neighbour-Joining starting tree automatically generated by the software. Nearest-Neighbour-Interchange (NNI) was used as the heuristic method for tree inference and 1000 bootstrap replicates were performed. The robustness of the trees was evaluated by 1000 bootstrap replications. Trees were visualized with TreeView v. 1.6.6 (Page 1996).

An initial ITS only phylogenetic analysis was carried out because for the species Diplodia huaxii, D. italica and D. pseudoplatani there are no tefl- $\alpha$ sequences available. However, since ITS alone cannot resolve all species in Diplodia an additional ITS plus tefl- $\alpha$ phylogenetic analysis was performed with all Diplodia species excluding the previously mentioned $D$. huaxii, D. italica and D. pseudoplatani.

\section{Pathogenicity test}

To verify the pathogenicity of each species investigated in this study, a field inoculation trial was conducted in August 2015 on asymptomatic P. lentiscus plants located on Caprera island $\left(41^{\circ} 12^{\prime} 26^{\prime} \mathrm{N}, 09^{\circ} 27^{\prime} 54^{\prime \prime} \mathrm{E}\right)$. During the experimental period, the daily mean air temperature was $20.3-31.5^{\circ} \mathrm{C}$. Six branches $(1-2.5 \mathrm{~cm}$ diameter) were inoculated with a representative isolate of each fungal species, and six uninoculated branches were used as controls. The inoculated region of the branch was surface-disinfected with $70 \%$ ethanol and a piece of outer and inner bark was removed with a flamed scalpel and replaced with an agar-mycelium plug taken from the margin of an actively growing colony on PDA. The inoculation site was covered with cotton wool soaked in sterile water and wrapped in a piece of aluminium foil secured with masking tape. Controls were inoculated with a sterile PDA plug applied as described above. After 1 month, the outer bark was carefully removed with a scalpel and the length of necrotic lesion surrounding each inoculation site was measured.

Re-isolation of inoculated species was attempted by transferring onto PDA 10 pieces of inner bark and wood taken from around the margin of each lesion. Cultures were grown in daylight and room temperature until fungal colonies developed.

\section{Statistical analyses}

Pathogenicity assay data were checked for normality, then subjected to analysis of variance (ANOVA). Significant differences among mean values were determined using Fisher's least significant differences multiple range test $(\mathrm{P}=0.05)$ after one-way ANOVA using XLSTAT software (Addinsoft, Paris, France). 


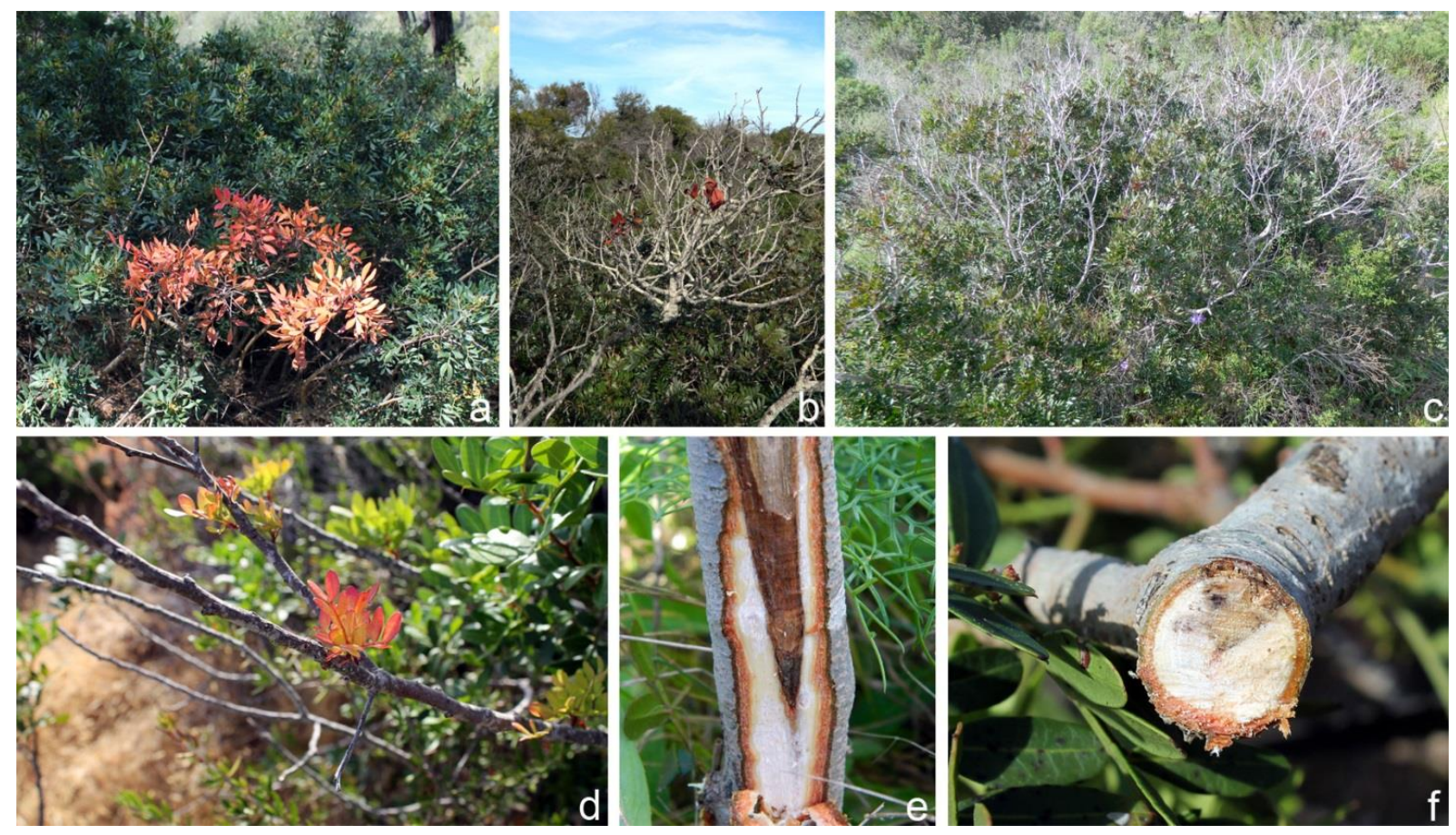

Fig. 1 - Disease symptoms observed in Pistacia lentiscus plants. a-c. Progressive dieback of twigs and branches. d. epicormic shoots along branches. e. wood necrosis visible after bark removal at level of a sunken cankers. f. cross section of a branch showing a characteristic wedge-shaped necrotic sector in the wood.

Table 3 Number of samples examined for each plot and associated fungi isolated.

\begin{tabular}{llllll}
\hline \multirow{2}{*}{ Island } & \multirow{2}{*}{ Plot } & \multicolumn{2}{l}{ Fungal species } & & \\
\cline { 3 - 6 } & & D. insularis & D. olivarum & N. cryptoaustrale & N. luteum \\
\hline Budelli & 1 & - & - & $2 / 3$ & $1 / 3$ \\
Caprera & 2 & $10 / 10$ & $2 / 10$ & - & - \\
& 3 & $5 / 8$ & $3 / 8$ & - & - \\
Mortorio & 4 & - & $1 / 6$ & $2 / 6$ & $1 / 6$ \\
Santa Maria & 5 & $3 / 3$ & - & - & - \\
Santo Stefano & 6 & - & $2 / 5$ & $2 / 5$ & - \\
Spargi & 7 & - & $2 / 2$ & - & - \\
\hline
\end{tabular}

\section{Results}

\section{Field surveys}

Out of 48 P. lentiscus plants investigated 37 displayed canopy disease symptoms, including the progressive dieback of twigs and branches associated with the abnormal growth of epicormic shoots (Fig. 1). Furthermore, symptomatic branches showed sunken cankers often associated with reddish brown exudations. After removing the outer and inner bark from cankers, dark brown necrotic lesions of variable size were visible on the xylem tissue. In cross-section, necrotic lesions appeared with the characteristic wedge-shaped aspect typical of Botryosphaeriaceae infections (Fig. 1).

\section{Fungal isolation and identification}

Isolation carried out from 37 cankered branch samples yielded a total of 36 fungal colonies belonging to the Botryosphaeriaceae. On the basis of morphological features and DNA sequence 
data (ITS and tef1- $\alpha$ ), three distinct species were identified: Diplodia olivarum (10 isolates), $N$. cryptoaustrale (6 isolates) and N. luteum (2 isolates) (Table 3). For each species BLAST searches against GenBank showed $99-100 \%$ identity to reference sequences of representative strains including those of ex-type isolates. In addition, eighteen Diplodia-like isolates on the basis of morphological features and DNA sequence data could not be assigned to any formerly described species. Although all processed samples showed the same symptoms the assemblages of pathogens associated was very different among the islands (Table 3). Diplodia olivarum was the species more widespread as it was isolated from plants in four of the six islands surveyed.

\section{Phylogenetic analyses}

The ITS ML analysis, as expected, did not resolve all species, especially within the clade containing D. sapinea, D. scrobiculata and other closely related species (Fig. 2). Within this large clade, the Diplodia-like isolates from lentisk (CBS 140350, BL99 and BL183) obtained in this study formed a separated and well-supported (89\% bootstrap) clade containing also isolates from narrowed-leaved ash (BL132 and BL133) and loquat (BN-55) from previous studies. This clade clustered with the clade containing D. alatafructa and D. pseudoseriata, which contained also the ex-type strain of $D$. pseudoplatani GUCC G603-1 that could not be separated from $D$. pseudoseriata CBS124906. Additionally, the ex-type strains of D. crataegicola MFLUCC 15-0648 and D. italica MFLUCC 14-1007 clustered together while the ex-type strains of $D$. huaxii MFLUCC 15-0648 and D. galiicola MFLUCC 15-0647 clustered with isolates previously identified as D. seriata including the ex-epitype strain CBS112555.

Combined ITS plus tefl- $\alpha$ ML analysis resolved all Diplodia species although not all species clades received high (>90\%) bootstrap support (Fig. 3). The only exceptions were $D$. scrobiculata/D. guayanensis and D. seriata/D. galiicola that did not form separate clades. The Diplodia-like isolates from lentisk (CBS 140350, BL99 and BL183) formed a separate and highly supported ( $98 \%$ bootstrap) clade clustering closely to the D. alatafructa and D. pseudoseriata clade with $100 \%$ bootstrap support.

\section{Taxonomy}

Diplodia insularis Linaldeddu, A. Alves \& A.J.L. Phillips, sp. nov.

Fig. 4 MycoBank: MB 818231

Facesoffungi number: FoF 02607 found.

Etymology - the epithet refers to the insular environments, where the species was originally

Sexual morph not seen. Conidiomata pycnidial, produced on Pistacia lentiscus twigs on 1/2 strength PDA within 2-4 weeks, solitary or aggregated, black, globose and uniloculate. Conidiophores absent. Conidiogenous cells hyaline, smooth, cylindrical, sometimes slightly swollen at the base, holoblastic, proliferating percurrently to form two or three distinct annellations or proliferating internally giving rise to periclinal thickenings, average of 20 conidiogenous cells $10.1 \times 3.9 \mu \mathrm{m}$. Conidia initially hyaline becoming pigmented even while still attached to the conidiogenous cell, dark brown when mature, unicellular, rarely septate, ellipsoid to ovoid, wall finely roughened on inner surface 18.2-(22.6)-25.9 × 9.1-(11.7)-14.4 $\mu \mathrm{m}, \pm$ S.D. $=22.6 \pm 1.4 \times$ $11.7 \pm 0.6 \mu \mathrm{m}, \mathrm{L} / \mathrm{W} 1.9 \pm 0.2 ; \mathrm{n}=50)$.

Culture characteristics - Colonies on PDA attained $90 \mathrm{~mm}$ diameter before 7 days in the dark at $25{ }^{\circ} \mathrm{C}$, the mycelium was moderately aerial, surface white at first and later turned pale grey to dark and dark in reverse.

Cardinal temperatures - Min. $\geq 5{ }^{\circ} \mathrm{C}$, max. $\leq 35^{\circ} \mathrm{C}$, opt. $25^{\circ} \mathrm{C}$. All isolates failed to grow at $35^{\circ} \mathrm{C}$, but growth resumed when plates were moved to $25^{\circ} \mathrm{C}$.

Known distribution - Caprera, Santa Maria, Sardinia (Italy) and Castellón (Spain).

Habitat - On cankered branches of Eriobotrya japonica, Fraxinus angustifolia and Pistacia lentiscus. 
Material examined - Italy, Santa Maria island, isolated from a branch canker of Pistacia lentiscus, 7 November 2013, Benedetto T. Linaldeddu, HOLOTYPE LISE 96309, a dried culture sporulating on Pistacia lentiscus twigs, culture ex-holotype CBS $140350=$ BL140. Other isolates examined are listed in Table 2.

Notes - Diplodia insularis is phylogenetically closely related to D. alatafructa and $D$. pseudoseriata. However, the latter two species can be distinguished from $D$. insularis by the size and shape of conidia as expressed as the L/W ratio of about 1.9 for D. insularis and about 2.2 for both $D$. alatafructa and D. pseudoseriata.

Diplodia scrobiculata J. de Wet, Slippers \& M.J. Wingf., Mycol. Res. 107: 562. 2003. MycoBank MB372427.

Synonym: Diplodia guayanensis F. Castro-Medina, J.R. Úrbez-Torres, S.R. Mohali \& W.D. Gubler, Plant Disease (http://dx.doi.org/10.1094/PDIS-05-16-0612-RE). MycoBank MB812480

Notes - According to Úrbez-Torres et al. (2016) D. guayanensis is closely related phylogenetically to $D$. scrobiculata but can be distinguished by its larger conidia and the presence of up to 4 septa in conidia while in D. scrobiculata conidia up to 3 septa may be present. Here we show that both species are indistinguishable in phylogenetic analyses. Also, morphological variability is common in these fungi making it unreliable for species differentiation (Phillips et al. 2013).

Diplodia seriata De Not., Micr. Ital. Dec. 4: 6. 1942. MycoBank MB180468.

Synonym: Diplodia galiicola Dissanayake, Camporesi \& K.D. Hyde, Fungal Diversity 75: 54. 2015, Facesoffungi: FoF00884.

Notes - According to Ariyawansa et al. (2015) D. galiicola is phylogenetically most closely related to D. seriata but can be distinguished by the shorter conidia. Here we show that both species are indistinguishable in phylogenetic analyses. Also, as already mentioned above morphological variability is common in these fungi making it unreliable for species differentiation (Phillips et al. 2013).

\section{Pathogenicity test}

All four Botryosphaeriaceae species proved to be pathogenic on P. lentiscus. At the end of the experimental period, all branches inoculated with $D$. insularis, D. olivarum, $N$. cryptoaustrale and $N$. luteum displayed dark brown bark lesions that spread up and down from the inoculation site (Fig. 5). The average lesion length differed significantly between species $\left(\mathrm{F}_{3,20}=14.013, \mathrm{P}<\right.$ 0.001 ; Tab. 4), e.g. the lesions caused by $N$. cryptoaustrale (mean $=7 \mathrm{~cm}$ ) were significantly larger than those caused by D. insularis (mean $=3.8 \mathrm{~cm})$, D. olivarum $($ mean $=2.6 \mathrm{~cm})$ and $N$. luteum (mean $=2.4 \mathrm{~cm}$ ). In addition, the branches inoculated with $D$. insularis and $N$. cryptoaustrale displayed wilting symptoms and a wedge-shaped necrotic sector in cross section congruent with field observations.

Control branches inoculated with sterile PDA plugs remained symptomless. All four fungal species were successfully re-isolated from symptomatic wood and inner bark tissues from all inoculated plants, thus fulfilling Koch's postulates (Tab. 4).

\section{Discussion}

This study represents the most comprehensive investigation of canker-causing agents of $P$. lentiscus to date in the Mediterranean region. For the first time the direct involvement of Botryosphaeriaceae species in the aetiology of canker and dieback symptoms of this important component of Mediterranean maquis was ascertained in various natural ecosystems. In particular, three fungal species belonging to two different genera were isolated and identified by means of morphological characters and DNA sequence data. These species included D. olivarum, $N$. cryptoaustrale and $N$. luteum. In addition, a novel species here described as Diplodia insularis was isolated. 


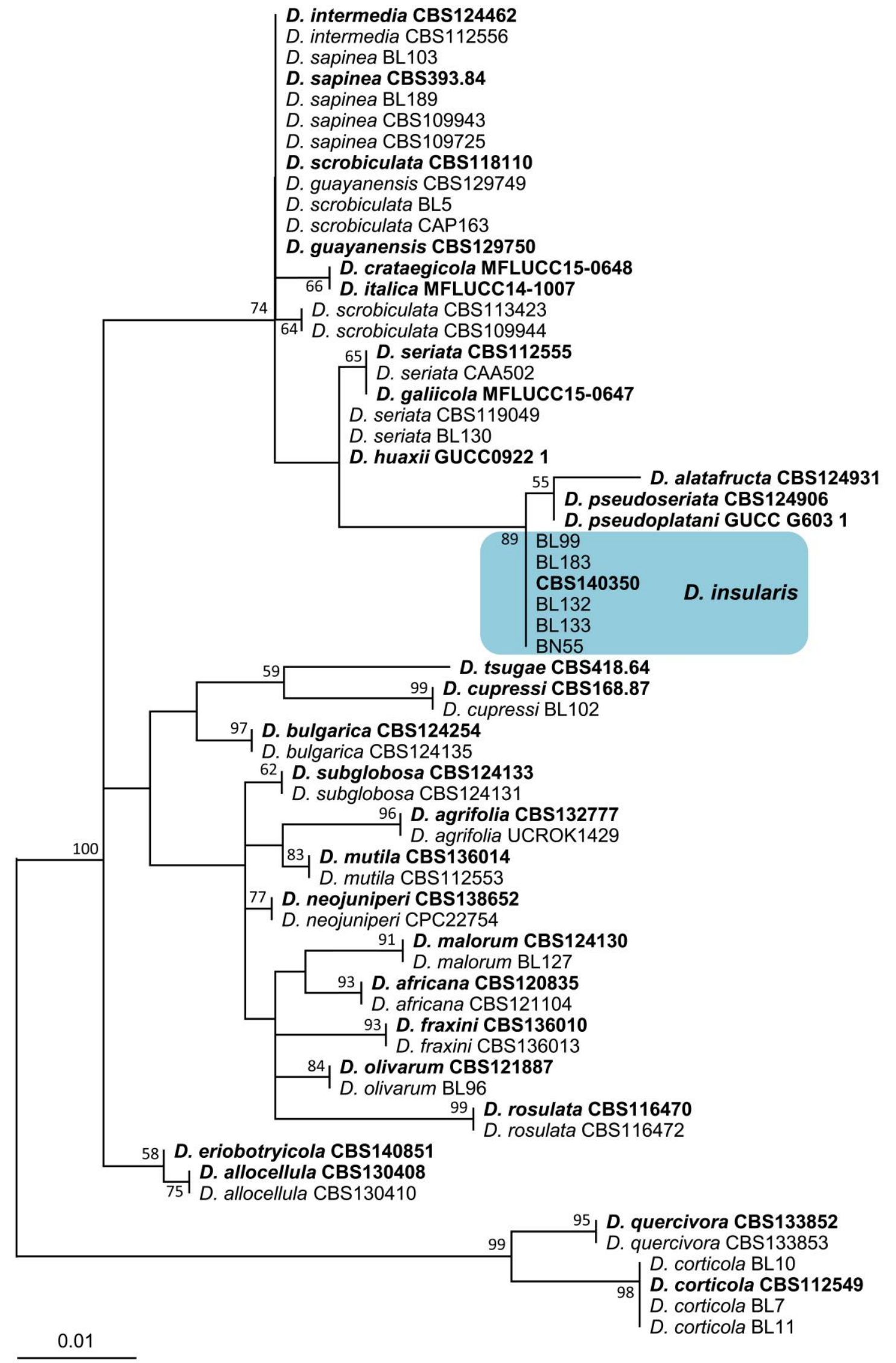

Fig.2 - Maximum Likelihood tree obtained from ITS sequence data and based on the Tamura 3parameter model. The rate variation model allowed for some sites to be evolutionarily invariable. The tree is drawn to scale, with branch lengths measured in the number of substitutions per site. Bootstrap support values in percentage (1000 replicates) are given at the nodes. 


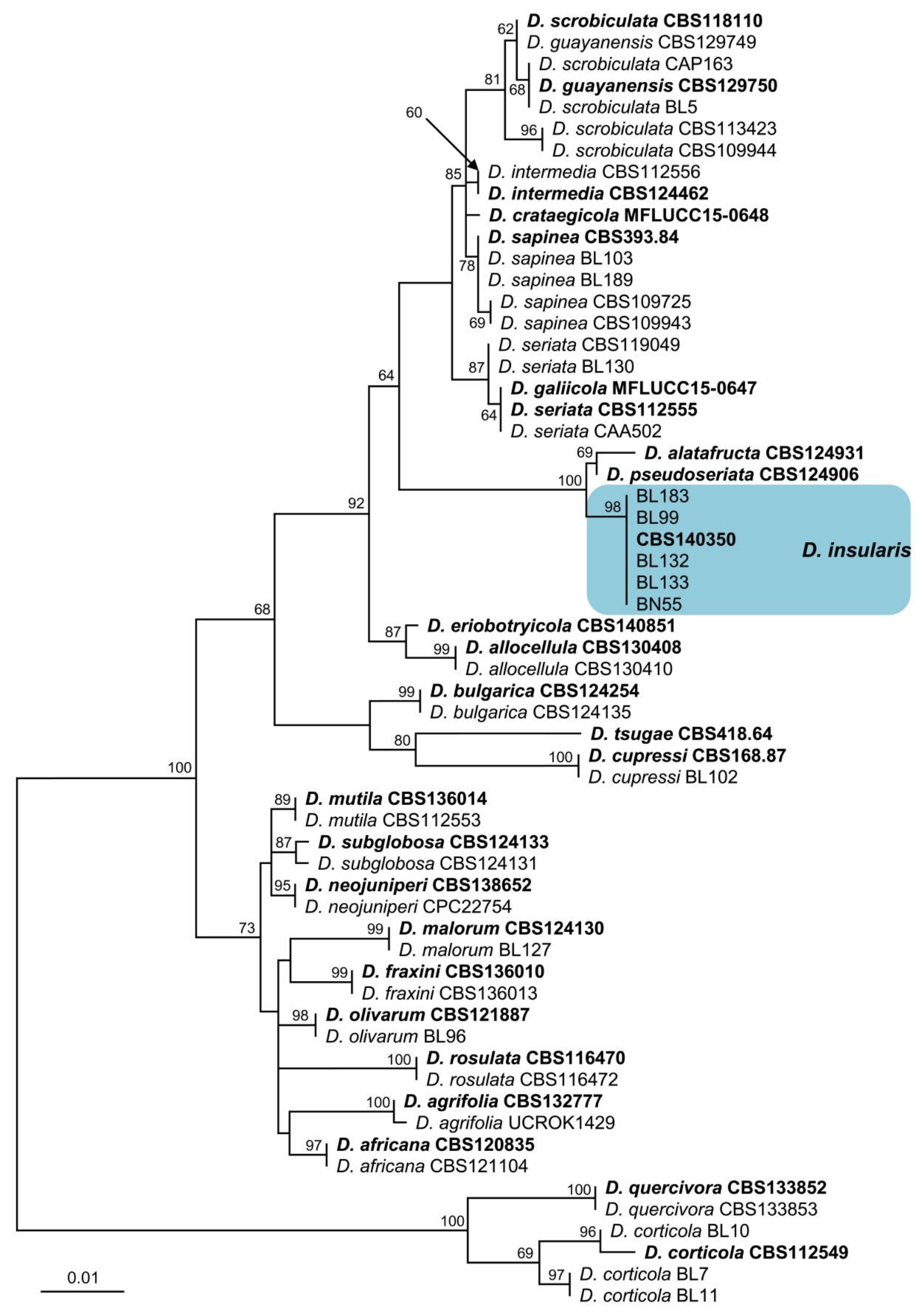

Fig. 3 - Maximum Likelihood tree obtained from combined ITS + tefl- $\alpha$ sequence data and based on the Hasegawa-Kishino-Yano model. A discrete Gamma distribution was used to model evolutionary rate differences among sites. The tree is drawn to scale, with branch lengths measured in the number of substitutions per site. Bootstrap support values in percentage (1000 replicates) are given at the nodes. 

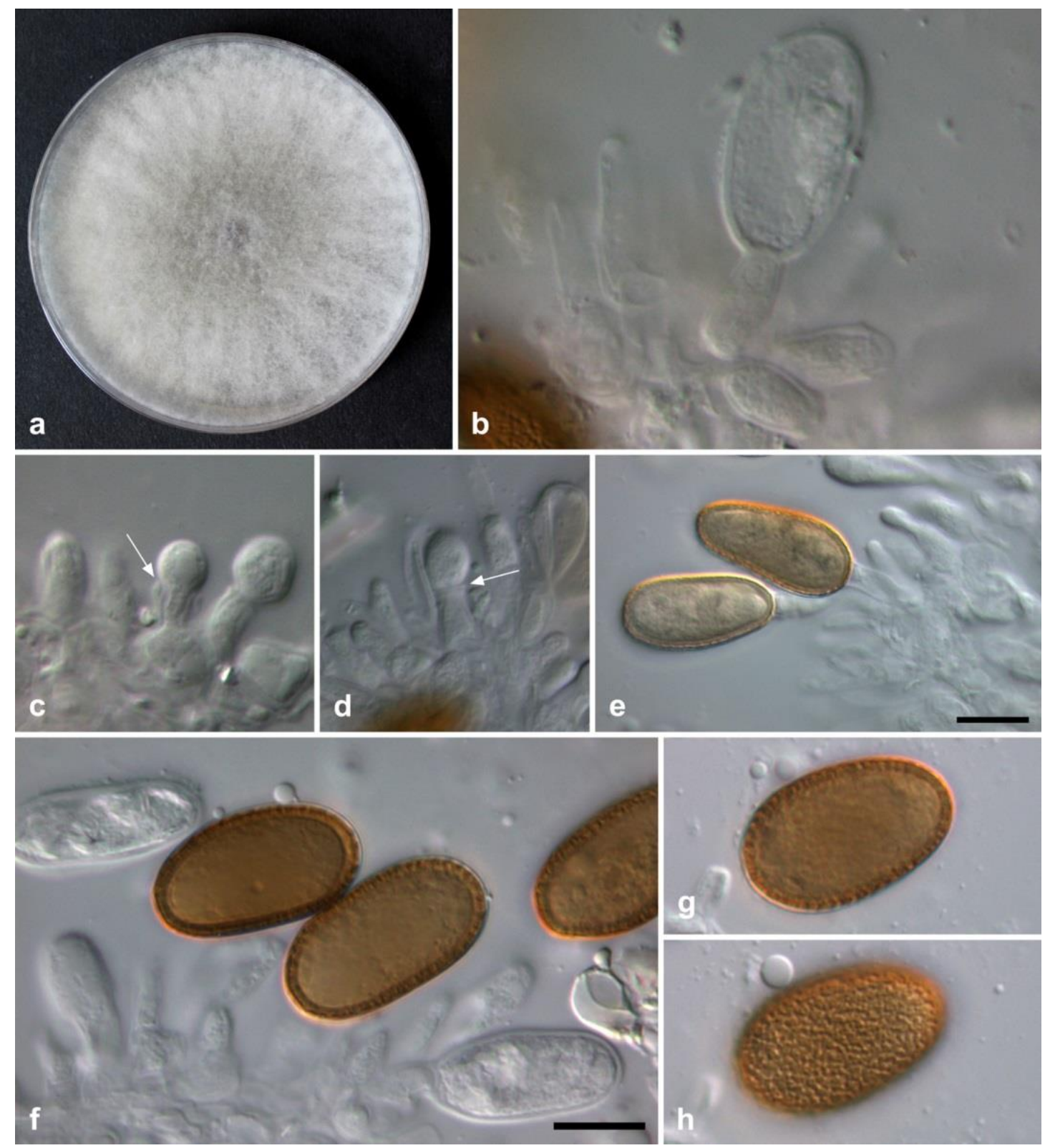

Fig. 4 - a. Colony morphology of Diplodia insularis after 7 days growth at $25{ }^{\circ} \mathrm{C}$ on PDA. b-d. hyaline immature conidia developing on conidiogenous cells. e. brown conidia still attached to the conidiogenous cell. f. mature conidia. $\mathbf{g}, \mathbf{h}$. two different focal planes to show the roughened inner surface of the conidium wall. Bars $=10 \mu \mathrm{m}$.

All four species are reported here for the first time on P. lentiscus. Strains of the new Diplodia species were first collected from declining Fraxinus angustifolia trees in Sardinia by Alves et al. (2014), but they did not introduce a new species to accommodate these strains, although the existence of important morphological and genetic differences between the fungal isolates from $F$. angustifolia and those belonging to the complex Diplodia alatafructa/Diplodia pseudoseriata were detected. These differences have been confirmed in the current study and the isolates obtained from $F$. angustifolia and P. lentiscus in Italy as well as a strain recently isolated from E. japonica in Spain by González-Domínguez et al. (2016), were considered representative of $D$. insularis. Morphologically, it is interesting to remark that in some species belonging to this Diplodia subclade, such as $D$. allocellula, $D$. eriobotryicola and $D$. insularis, conidia become pigmented while still attached to the conidiogenous cell, similar to what is seen in species of Dothiorella and Spencermartinsia. This has also been reported for D. seriata, D. pinea, D. intermedia and D. scrobiculata (Phillips et al. 2013). 

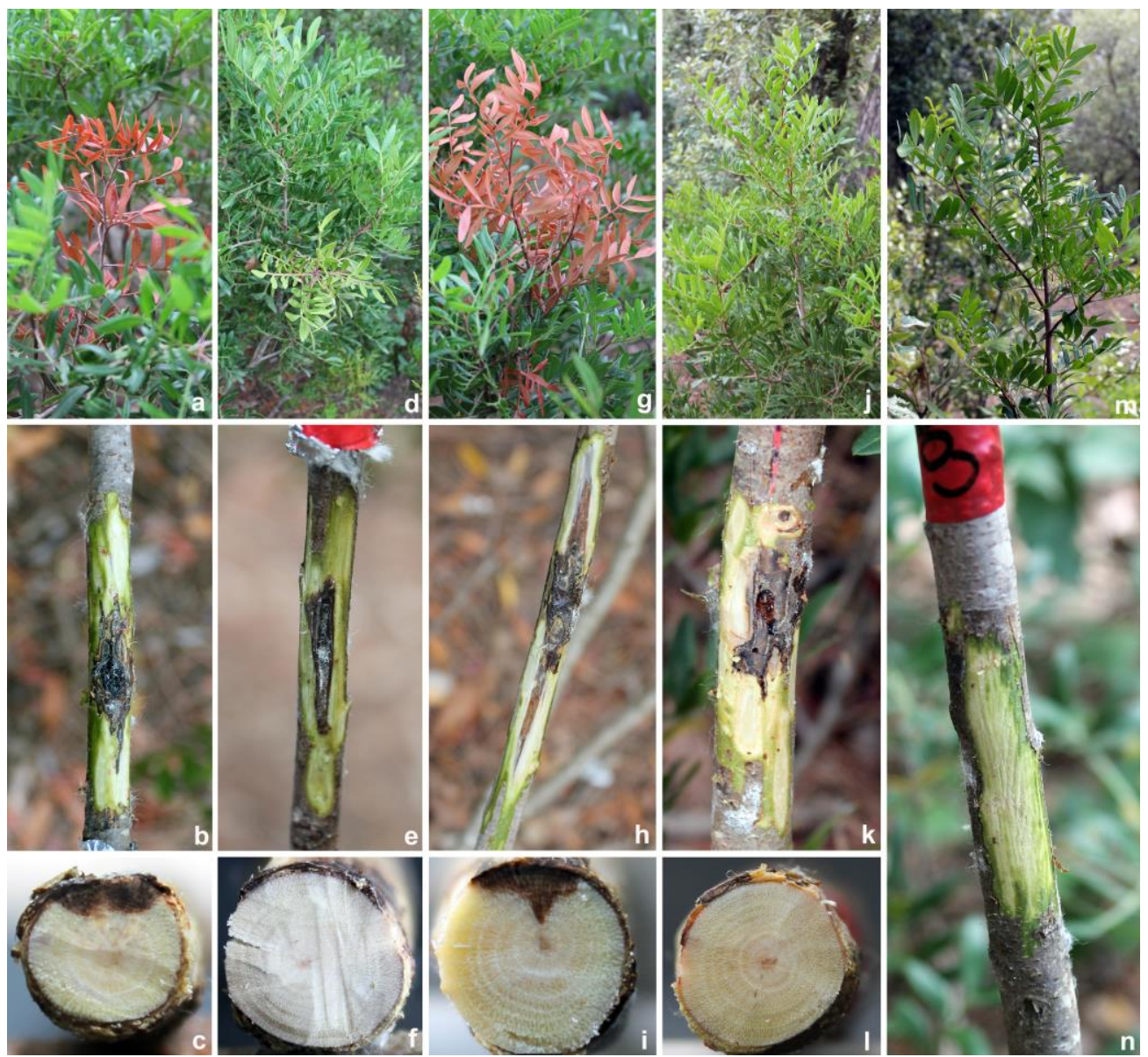

Fig. 5 - Symptoms observed on Pistacia lentiscus branches 30 days after inoculation with, a-c Diplodia insularis. d-f. Diplodia olivarum. $\mathbf{g - \mathbf { i }}$. Neofusicoccum cryptoaustrale. $\mathbf{j}-\mathbf{l}$. Neofusicoccum luteum. m, n. Control branches.

Table 4 Mean lesion length \pm standard deviation caused by fungal species on branches of Pistacia lentiscus.

\begin{tabular}{|c|c|c|c|c|c|}
\hline \multirow{2}{*}{ Fungal species } & \multicolumn{3}{|c|}{ Details of strains inoculated } & \multirow{2}{*}{$\begin{array}{l}\text { Mean lesion } \\
\text { length }(\mathrm{cm})\end{array}$} & \multirow{2}{*}{$\begin{array}{l}\text { Re-isolation } \\
\text { frequency } \%\end{array}$} \\
\hline & Code & ITS & tefl- $\alpha$ & & \\
\hline Diplodia insularis & BL140 & KX833072 & KX833073 & $3.8 \pm 0.7 \mathrm{~b}$ & 100 \\
\hline Diplodia olivarum & BL96 & KX833078 & KX833079 & $2.6 \pm 0.6 \mathrm{~b}$ & 100 \\
\hline Neofusicoccum cryptoaustrale & BL94 & KX833084 & KX833085 & $7.0 \pm 2.5 \mathrm{a}$ & 100 \\
\hline Neofusicoccum luteum & BL95 & KX833086 & KX833087 & $2.4 \pm 0.7 b$ & 100 \\
\hline Control & & & & 0.00 & \\
\hline LSD critical value & & & & 2.79 & \\
\hline
\end{tabular}

Phylogenetic analysis based on the ITS region raised some doubts about the status of the recently described species $D$. huaxii, D. italica and D. pseudoplatani (Wijayawardene et al. 2016). However, the ITS region is known to be insufficient to accurately discriminate species in Diplodia. Thus, this issue can only be clarified when tefl- $\alpha$ sequences are available for these species. In ITS plus tefl- $\alpha$ phylogenetic analysis the ex-type of $D$. galiicola clustered with the ex-epitype of $D$. seriata and both species could not be separated. A comparison of the sequences from both species showed that the differences reported between them are located at the start of the tefl- $\alpha$ sequence of D. galiicola. This part of the tefl- $\alpha$ sequence, although located in a very conserved region, was highly divergent compared to all other Diplodia species, which suggests sequencing errors and lack of editing. For this reason, it was excluded from the alignments and coded as missing data. 
Additionally, combined ITS and tefl- $\alpha$ phylogeny showed that the recently described $D$. guayanensis and D. scrobiculata (Úrbez-Torres et al. 2016) cannot be differentiated. A careful examination of sequence alignments showed that there are no differences in the ITS sequence and no fixed polymorphisms in the tefl- $\alpha$ sequences of $D$. guayanensis and the ex-type isolate of $D$. scrobiculata CBS118110 (= CMW189). Apparently these two species differ in a single nucleotide in the sequence of the $\beta$-tubulin gene. The differences between our results and those reported by Úrbez-Torres et al. (2016) arise from the fact that those authors used in their phylogenetic analyses older sequences for D. scrobiculata (ITS: AY253292 and tef1- $\alpha$ : AY624253) while we used more recent ones (ITS: KF766160 and EF: KF766399). Comparing the sequences it is evident that the older ones are shorter and contain sequencing errors. Thus, for the reasons explained above, $D$. guayanensis is considered as a synonym of D. scrobiculata and D. galiicola a synonym of $D$. seriata.

The pathogenicity of all Botryosphaeriaceae species obtained in this study was confirmed through an inoculation experiment in the field. All isolates tested were able to cause necrotic lesions and the isolate of $N$. cryptoaustrale proved to be highly aggressive. Neofusicoccum cryptoaustrale has previously been reported as an aggressive pathogen on other woody hosts in Sardinia such as Vitis vinifera and Juniperus phoenicea (Linaldeddu et al. 2010, Andolfi et al. 2012). The high degree of aggressiveness observed in this study for $D$. insularis is in agreement with the results obtained by González-Domínguez et al. (2016) on E. japonica in Spain.

Diplodia olivarum was first reported from rotting olive drupes and cankered branches of Ceratonia siliqua in Italy (Lazzizera et al. 2008, Granata et al. 2011). Subsequently it was reported as associated with declining Prunus dulcis trees in Spain (Gramaje et al. 2012) and cankered branches of Quercus coccifera in Tunisia (Alves et al. 2014).

Neofusicoccum luteum is emerging as a common and cosmopolitan species on diverse host plants, and it is now recognized as an aggressive pathogen of Crataegus mexicana, Eucalyptus camaldulensis, Olea europaea, Persea americana, Quercus robur, Rhododendron spp., Syzygium cordatum and V. vinifera (Pavlic et al. 2007, McDonald et al. 2009, Sergeeva et al. 2009, Pintos Varela et al. 2011, Amponsah et al. 2012, Adesemoye et al. 2013, Barradas et al. 2013, Deidda et al. 2016). Furthermore, $N$. luteum has recently been reported as a pathogen of E. arborea on Caprera island (Linaldeddu et al. 2015b). Erica arborea represents a "sporulation host" for $N$. luteum, large numbers of conidiomata and ascomata develop on infected shoots throughout the year, which serve as an important inoculum source (Linaldeddu unpublished data).

Members of Botryosphaeriaceae family represent a growing threat to agricultural crops, urban and natural forest ecosystems in Sardinia (Linaldeddu et al. 2014, 2015a, 2016). In particular, over the last few years there has been an exponential increase in the occurrence of diseases caused by species of this family in natural areas on the east coast of Sardinia, in particular on the islands of the La Maddalena archipelago, where in a limited geographic area of about 5,134 hectares, the involvement of 16 different species in the aetiology of new or unusual diseases of species of Mediterranean maquis have been detected (Linaldeddu unpublished data). This finding raises questions about the origin, introduction and pathway of these fungi as well as underlining the need to develop suitable actions to limit their further spread.

\section{Acknowledgements}

This research was supported by grants from the National Park of the La Maddalena archipelago. The authors would like to thank Paola Brundu who provided help and logistic support and Antonio Deidda for his invaluable assistance during field sampling and morphological analysis. Artur Alves acknowledges financing from European Funds through COMPETE and National Funds through the Portuguese Foundation for Science and Technology (FCT) to research unit CESAM (UID/AMB/50017/2013 - POCI-01- 0145-FEDER-007638), himself (FCT Investigator Programme - IF/00835/2013) and support by the Autonomous Region of Sardinia, Visiting Professor Programme at the University of Sassari, Italy. 


\section{References}

Adesemoye AO, Mayorquin JS, Eskalen A. 2013 - Neofusicoccum luteum as a pathogen on Tejocote (Crataegus mexicana). Phytopathologia Mediterranea 52, 123-129.

Alves A, Linaldeddu BT, Deidda A, Scanu B, Phillips AJL. 2014 - The complex of Diplodia species associated with Fraxinus and some other woody hosts in Italy and Portugal. Fungal Diversity 67, 143-156.

Amponsah NT, Jones EE, Ridgway HJ, Jaspers MV. 2012 - Susceptibility of grapevine tissues to Neofusicoccum luteum conidial infection. Plant Pathology 61, 719-729.

Andolfi A, Maddau L, Cimmino A, Linaldeddu BT, Franceschini A, Serra S, Basso S, Melck D, Evidente A. 2012 - Cyclobotryoxide, a phytotoxic metabolite produced by the plurivorous pathogen Neofusicoccum australe. Journal of Natural Products 75, 1785-1791.

Ariyawansa HA, Hyde KD, Jayasiri SC, Buyck B, Chethana KWT, Dai DQ, Dai YC, Daranagama DA, Jayawardena RS, Lücking R, Ghobad-Nejhad M, Niskanen T, Thambugala KM, Voigt K, Zhao RL, Li GJ, Doilom M, Boonmee S, Yang ZL, Cai Q, Cui YY, Bahkali AH, Chen J, Cui BK, Chen JJ, Dayarathne MC, Dissanayake AJ, Ekanayaka AH, Hashimoto A, Hongsanan S, Gareth Jones EB, Larsson E, Li WJ, Li QR, Liu JK, Luo ZL, Maharachchikumbura SSN, Mapook A, McKenzie EHC, Norphanphoun C, Konta S, Pang KL, Perera RH, Phookamsak R, Phukhamsakda C, Pinruan U, Randrianjohany E, Singtripop C, Tanaka K, Tian CM, Tibpromma S, Abdel-Wahab MA, Wanasinghe DN, Wijayawardene NN, Zhang JF, Zhang H, Abdel-Aziz FA, Wedin M, Westberg M, Ammirati JF, Bulgakov TS, Lima DX, Callaghan TM, Callac P, Chang CH, Coca LF, DalForno M, Dollhofer V, Fliegerová K, Greiner K, Griffith GW, Ho HM, Hofstetter V, Jeewon R, Kang JC, Wen TC, Kirk PM, Kytövuori I, Lawrey JD, Xing J, Li H, Liu ZY, Liu XZ, Liimatainen K, Lumbsch HT, Matsumura M, Moncada B, Nuankaew S, Parnmen S, de Azevedo Santiago ALCM, Sommai S, Song Y, de Souza CAF, de Souza-Motta CM, Su HY, Suetrong S, Wang Y, Wei SF, Wen TC, Yuan HS, Zhou LW, Réblová M, Fournier J, Camporesi E, Luangsa-ard JJ, Tasanathai K, Khonsanit A, Thanakitpipattana D, Somrithipol S, Diederich P, Millanes AM, Common RS, Stadler M, Yan JY, Li XH, Lee HW, Nguyen TTT, Lee HB, Battistin E, Marsico O, Vizzini A, Vila J, Ercole E, Eberhardt U, Simonini G, Wen HA, Chen XH, Miettinen O, Spirin V, Hernawati. 2015 - Fungal diversity notes 111-252-taxonomic and phylogenetic contributions to fungal taxa. Fungal Diversity 75, 27-274.

Barradas C, Correia A, Alves A. 2013 - First report of Neofusicoccum australe and N. luteum associated with canker and dieback of Quercus robur in Portugal. Plant Disease 97, 560.

Biondi E, Bagella S. 2005 - Vegetazione e paesaggio vegetale dell'arcipelago di La Maddalena (Sardegna nord-orientale). Fitosociologia 42, 3-99.

Bocchieri E. 1992 - Flora of the small islands of the archipelago of Maddalena (north-eastern Sardinia) and floristic contributions regarding some of the mains islands of the archipelago. Flora Mediterranea 2, 33-64.

Crous PW, Gams W, Stalpers JA, Robert V, Stegehuis G. 2004 - MycoBank: an online initiative to launch mycology into the $21^{\text {st }}$ century. Studies in Mycology 50, 19-22.

Deidda A, Buffa F, Linaldeddu BT, Pinna C, Scanu B, Deiana V, Satta A, Franceschini A, Floris I. 2016 - Emerging pests and diseases threaten Eucalyptus camaldulensis plantations in Sardinia, Italy. Iforest (doi: 10.3832/ifor1805-009).

González-Domínguez E, Alves A, León M, Armengola J. 2016 - Characterization of Botryosphaeriaceae species associated with diseased loquat (Eriobotrya japonica) in Spain. Plant Pathology (doi: 10.1111/ppa.12556).

Gramaje D, Agustí-Brisach C, Pérez-Sierra A, Moralejo E, Olmo D, Mostert L, Damm U, Armengol J. 2012 - Fungal trunk pathogens associated with wood decay of almond trees on Mallorca (Spain). Persoonia 28, 1-13. 
Granata G, Faedda R, Sidoti A. 2011 - First report of canker disease caused by Diplodia olivarum on carob tree in Italy. Plant Disease 95, 776.

Hall TA. 1999 - BioEdit: a user-friendly biological sequence alignment editor and analysis program for Windows 95/98/NT. Nucleic Acids Symposium Series 41, 95-98.

Inderbitzin P, Bostock RM, Trouillas FP, Michailides TJ. 2010 - A six-locus phylogeny reveals high species diversity in Botryosphaeriaceae from California almond. Mycologia 102, 1350-1368.

Jayasiri SC, Hyde KD, Ariyawansa HA, Bhat DJ, Buyck B, Cai L, Dai YC, Abd-Elsalam KA, Ertz D, Gibertoni TB, Hidayat I, Jeewon R, Jones EBG, Karunarathna SC, Kirk P, Li WJ, Liu JK, Luangsa-ard JJ, Maharachchikumbura SSN, Manamgoda DS, McKenzie EHC, Moncalvo JM, Ghobad-Nejhad M, Nilsson H, Pang KL, Pereira OL, Raspé O, Rollins AW, Romero AI, Salazar JAE, Stephenson S, Suetrong S, Taylor JE, Tsui CKM, Vizzini A, Abdel-Wahab MA, Wen TC, Boonmee S, Dai DQ, Daranagama DA, Dissanayake AJ, Ekanayaka AH, Hongsanan S, Jayawardena RS, Perera RH, Phookamsak R, De Silva NI, Thambugala KM, Tian Q, Wanasinghe DN, Wijayawardene NN, Zhao RL, Kang JC, Promputtha I. 2015 - The Faces of Fungi database - A unique perspective: Fungal names linked with morphology, phylogeny and human impacts. Fungal Diversity 74, 3-18.

Lazzizera C, Frisullo S, Alves A, Lopes J, PhillipsAJL. 2008 - Phylogeny and morphology of Diplodia species on olives in southern Italy and description of Diplodia olivarum. Fungal Diversity 31, 63-71.

Linaldeddu BT, Alves A and Phillips AJL 2016 - Sardiniella urbana gen. et sp. nov., a new member of the Botryosphaeriaceae isolated from declining Celtis australis trees in Sardinian streetscapes. Mycosphere doi: 10.5943/mycosphere/si/1b/5

Linaldeddu BT, Deidda A, Scanu B, Franceschini A, Serra S, Berraf-Tebbal A, Zouaoui Boutiti M, Ben Jamâa ML, Phillips AJL. 2015a - Diversity of Botryosphaeriaceae species associated with grapevine and other woody hosts in Italy, Algeria and Tunisia, with descriptions of Lasiodiplodia exigua and Lasiodiplodia mediterranea sp. nov. Fungal Diversity 71, 201214.

Linaldeddu BT, Franceschini A, Alves A, Phillips AJL. 2013 - Diplodia quercivora sp. nov.: a new species of Diplodia found on declining Quercus canariensis trees in Tunisia. Mycologia $105,1266-1274$.

Linaldeddu BT, Scanu B, Maddau L, Franceschini A. 2011 - Diplodia africana causing dieback disease on Juniperus phoenicea: a new host and first report in the northern hemisphere. Phytopathologia Mediterranea 50, 473-477.

Linaldeddu BT, Scanu B, Maddau L, Franceschini A. 2014 - Diplodia corticola and Phytophthora cinnamomi: the main pathogens involved in holm oak decline on Caprera island (Italy). Forest Pathology 44, 191-200.

Linaldeddu BT, Scanu B, Schiaffino A, Serra S. 2010 - First report of Neofusicoccum australe associated with grapevine cordon dieback in Italy. Phytopathologia Mediterranea 49, 417420.

Linaldeddu BT, Scanu B, Seddaiu S, Deidda A, Maddau L, Franceschini A. 2015b - A new disease of Erica arborea in Italy caused by Neofusicoccum luteum. Phytopathologia Mediterranea 54, 124-127.

McDonald V, Lynch S, Eskalen A. 2009 - First report of Neofusicoccum australe, N. luteum, and N. parvum associated with avocado branch canker in California. Plant Disease 93, 967.

Page RD. 1996 - TreeView: an application to display phylogenetic trees on personal computers. Computer Applications in the Biosciences 12, 357-358.

Pavlic D, Slippers B, Coutinho TA, Wingfield MJ. 2007 - Botryosphaeriaceae occurring on native Syzygium cordatum in South Africa and their potential threat to Eucalyptus. Plant Pathology $56,624-636$. 
Phillips AJL, Alves A, Abdollahzadeh J, Slippers B, Wingfield MJ, Groenewald JZ, Crous PW 2013 - The Botryosphaeriaceae: genera and species known from culture. Studies in Mycology 76, 51-167.

Pintos Varela C, Redondo Fernández V, Mansilla Vázquez JP, Aguín Casal O. 2011 - First report of dieback on hybrid rhododendrons caused by Neofusicoccum luteum and N. parvum in Spain. Plant Disease 95, 221.

Sergeeva V, Alves A, Phillips AJL. 2009 - Neofusicoccum luteum associated with leaf necrosis and fruit rot of olives in New South Wales, Australia. Phytopathologia Mediterranea 48, 294298.

Tamura K, Stecher G, Peterson D, Filipski A, Kumar S. 2013 - MEGA6: molecular evolutionary genetics analysis version 6.0. Molecular Biology and Evolution 30, 2725-2729.

Thompson JD, Gibson TJ, Plewniak F, Jeanmougin F, Higgins DG. 1997 - The CLUSTAL_X windows interface: flexible strategies for multiple sequence alignment aided by quality analysis tools. Nucleic Acids Research 25, 4876-4882.

Úrbez-Torres JR, Castro-Medina F, Mohali SR, Gubler WD. 2016 - Botryosphaeriaceae species associated with cankers and dieback symptoms of Acacia mangium and Pinus caribaea var. hondurensis in Venezuela. Plant Disease (in press) doi: 10.1094/PDIS-05-16-0612-RE

White TJ, Bruns T, Lee S, Taylor J. 1990 - Amplification and direct sequencing of fungal ribosomal RNA genes for phylogenetics. In: PCR Protocols, a Guide to Methods and Applications (eds. MA Innis, DH Gelfand, JJ Sninsky and J White) Academic Press. San Diego, Ca, USA 315-322.

Wijayawardene NN, Hyde KD, Wanasinghe DN, Papizadeh M, Goonasekara ID, Camporesi E, Jayarama Bhat D, McKenzie EHC, Phillips AJL, Diederich P, Tanaka K, Li WJ, Tangthirasunun N, Phookamsak R, Dai DQ, Dissanayake AJ, Weerakoon G, Maharachchikumbura SSN, Hashimoto A, Matsumura M, Bahkali AH, Wangshow Y. 2016 - Taxonomy and phylogeny of dematiaceous coelomycetes. Fungal Diversity 77, 1-316. 